\title{
Advanced Oxidation Processes in Food Industry Wastewater Treatment - A Review
}

\author{
Anne Heponiemi ${ }^{1}$ and Ulla Lassi $i^{1,2}$ \\ ${ }^{1}$ Department of Chemistry, University of Oulu, Oulu \\ ${ }^{2}$ Kokkola University Consortium Chydenius, Kokkola \\ Finland
}

\section{Introduction}

The food industry uses large amounts of water for many different purposes including cooling and cleaning, as a raw material, as sanitary water for food processing, for transportation, cooking and dissolving, as auxiliary water etc. In principle, the water used in the food industry may be used as process and cooling water or boiler feed water (EC, 2006). In 2008, for example, the total industrial water consumption in Finland was 7600 million $\mathrm{m}^{3}$ of which 34.5 million $\mathrm{m}^{3}$ was used by the food processing industry (Finnish Food and Drink Industries`Federation, 2010).

As a consequence of diverse consumption, the amount and composition of food industry wastewaters varies considerably. Characteristics of the effluent consist of large amounts of suspended solids, nitrogen in several chemical forms, fats and oils, phosphorus, chlorides and organic matter (Finnish Food and Drink Industries` Federation, 2005). Generally, the BOD (biochemical oxygen demand) and COD (chemical oxygen demand) of food industry wastewater is 10 or even 100 times higher than those of domestic wastewater (EC, 2006). Unpleasant odours are also a typical problem in food industry wastewaters. These odours are usually the result of gases (hydrogen sulphide, indole) produced by the anaerobic decomposition of organic matter (Metcalf \& Eddy, 2003).

\section{Characteristics of food industry wastewaters}

Considering the legislation of wastewater purification, total suspended solids (TSS), organic matter, total nitrogen $\left(\mathrm{N}_{\text {tot }}\right)$ and phosphorus $\left(\mathrm{P}_{\text {tot }}\right)$ must be removed from both municipal and industrial wastewaters before being released into the watercourse (Metcalf \& Eddy, 2003).

In 2008 in Finland, the amount of food processing industry wastewater was 4.1 million $\mathrm{m}^{3}$ and the total amount of industrial wastewaters was 1130 million $\mathrm{m}^{3}$ (Table 1) (Finnish Environment Institute, 2009).

In 2008, the amount of total suspended solids was 83 tonnes, $\mathrm{P}_{\text {tot }} 4$ tonnes, $\mathrm{N}_{\text {tot }} 87$ tonnes whilst the proportion of food industry wastewater of the total industry wastewaters was around $0.4 \%$. However, the volume of organic matter in food industry wastewater was notable: $0.024 \mathrm{~kg} \mathrm{~m}^{-3}$ when for example, compared to $\mathrm{BOD}_{7}$ in the pulp and paper industry $\left(0.015 \mathrm{~kg} \mathrm{~m}^{-3}\right)$ (Finnish Environment Institute, 2009). 


\begin{tabular}{lrrrrrr}
\hline Industry & $\begin{array}{r}\mathbf{1 0 0 0 ~}^{\mathbf{3}} \\
\text { Wastewater }\end{array}$ & $\mathbf{T S S}$ & $\mathbf{P}_{\text {tot }}$ & $\begin{array}{r}\mathbf{t} / \mathbf{a} \\
\mathbf{N}_{\text {tot }}\end{array}$ & BOD $_{\mathbf{7}}$ & $\mathbf{C O D}_{\mathbf{C r}}$ \\
\hline Pulp and paper industry & 677058 & 14787 & 161 & 2347 & 10148 & 160813 \\
Metal industry & 208613 & 493 & 2 & 224 & 4 & 70 \\
Chemical industry & 115192 & 1193 & 14 & 435 & 217 & 2174 \\
Mining and quarry industry & 20449 & 431 & 1 & 69 & 7 & 686 \\
Food industry & 4067 & 83 & 4 & 87 & 99 & 290 \\
Others & 104981 & 628 & 9 & 42 & 272 & 1819 \\
\hline Total & $\mathbf{1 1 3 0 3 6 0}$ & $\mathbf{1 7 6 1 5}$ & $\mathbf{1 9 1}$ & $\mathbf{3 2 0 4}$ & $\mathbf{1 0 7 4 7}$ & $\mathbf{1 6 5 8 5 2}$ \\
\hline
\end{tabular}

Table 1. Industrial discharge into the watercourse in 2008 in Finland (Finnish Environment Institute, 2009).

\subsection{Total suspended solids}

The most important physical factor of wastewater is its total solid content which is comprised of floating, settleable and colloidal matter, and matter in a solution. In the characterisation of various solids in wastewater, samples can be classified in ten different fractions. The most important fraction of these is total suspended solids (TSS) which is one of the two universally used effluent standards (along with BOD) to follow the performance of wastewater treatment plants (Metcalf \& Eddy, 2003). The TSS of wastewater is determined according to APHA standard 2540 D. “Total Suspended Solids Dried at 103-105 ${ }^{\circ} \mathrm{C} "$ (APHA, 1998).

The solid matter of food industry wastewater can also vary considerably. For example in the slaughterhouse and meat industry wastewaters, the solid matter is composed of hairs, feathers, bowels and piece of tissues (Hiisvirta, 1976) compared to potato and vegetable industry wastewaters whose suspended solids are soil, peels and other vegetable parts (Lehto et al., 2007). Typically, food industry wastewaters contain lots of floating suspended solids which have to be removed since releasing it directly to the watercourse increases sediment (Metcalf \& Eddy, 2003).

\subsection{Organic matter}

Organic compounds consist mainly of carbon, hydrogen and oxygen. The organic matter in wastewaters is typically a mixture of proteins and carbohydrates as well as oils and fats. In the slaughterhouse and meat industry wastewaters, for example, the organic content is mainly composed of grease which can be solid, suspended or emulsified (Hiisvirta, 1976). The low solubility of fats and oils reduces the rate of their biological decomposition and in the wastewater treatment plant, fats can block up the treatment devices of wastewaters. If grease is not removed before the discharge of treated wastewater, it can interfere with the biological life in surface waters. Wastewater also contains urea and small quantities of very large number of simple and extremely complex synthetic organic molecules (Metcalf \& Eddy, 2003).

There are a number of different analyses to determine the organic content of wastewater. The analyses can be divided into those used to measure aggregate organic matter content of wastewater and those analyses used to quantify individual organic compounds (APHA, 1998). Typically, only aggregate organic matter content is measured. Those are: biochemical 
oxygen demand (BOD), chemical oxygen demand (COD) and total organic carbon (TOC) (Metcalf \& Eddy, 2003).

\subsubsection{Biochemical oxygen demand}

The most widely used parameter for the determination of organic matter in wastewater is BOD. In this method, the biodegradable organic matter of wastewater is measured. The biochemical oxygen demand is the amount of oxygen which organic matter (solid or dissolved) in the water is consumed when biodegradation occurs in biological oxygen containing states (SFS-EN 1899-1). There are numerous standards for the determination of BOD such as SFS-EN 1899-1 (SFS-EN 1899-1), APHA standard 5210 B (APHA, 1998) and OECD 301 F-guide (OECD, 1992). For wastewater samples, the standard measuring time is five days $\left(\mathrm{BOD}_{5}\right)$ at $20^{\circ} \mathrm{C}$, but other lengths of time and temperatures can also be used. In Finland, for example, the typical measuring time is seven days $\left(\mathrm{BOD}_{7}\right)$ (Karttunen, 2003).

Although there is a high content of organic matter in food industry wastewaters, the organic compounds, such as fats and proteins, are usually easily biodegradable. Furthermore, the large amount of micro-organisms, for example in the slaughterhouse and meat processing industry wastewaters, facilitates the decomposition of organic compounds (Hiisvirta, 1976). However, there are also some exceptions such as food industry wastewaters containing salts, disinfectants and cleaning agents (Finnish Food and Drink Industries` Federation, 2005).

\subsubsection{Chemical oxygen demand}

Chemical oxygen demand describes the number of chemically oxidising organic compounds of wastewater (SFS 3020). The COD value can be determined according to APHA standard 5220 "Chemical oxygen demand (COD)". For wastewaters, the oxidising agent is dichromate in an acid solution (APHA, 1998). The ratio of the BOD and COD can provide more information about the wastewater sample. Usually, for industrial wastewaters, COD is higher than BOD because many organic substances which are difficult to oxidise biologically can be oxidised chemically. If the COD value is much bigger than the BOD value, the organic compounds in wastewater are slowly biodegradable (Hiisvirta, 1976). In food industry wastewaters, the COD and BOD values are often closely matched to each other due to the easily biodegradable organic compounds of the effluent (Finnish Food and Drink Industries`Federation, 2005).

\subsubsection{Total organic carbon}

Total organic carbon (TOC) describes the amount of organic compounds in wastewater and is used as a more convenient and directs expression of the total organic content than either BOD or COD. TOC analysis provides different information to BOD or COD because the unit of the TOC value is [mg C L-1] while measuring BOD and COD uses the unit of $\mathrm{mg} \mathrm{O}_{2} \mathrm{~L}^{-1}$. TOC is also independent of the oxidation state of the organic matter and does not measure other organically bound elements, such as nitrogen and hydrogen, and inorganic compounds that can contribute to the oxygen demand measured by BOD and COD (APHA, 1998). The analysing methods for TOC utilises heat and oxygen, UV radiation, chemical oxidants, or a combination of these to decompose the organic compounds of the sample to 
carbon dioxide which is measured with an infrared analyser, conductivity or by some other method (Metcalf \& Eddy, 2003). The inorganic carbon content of the wastewater sample can be many times greater than the TOC fraction. Therefore, the inorganic carbon $\left(\mathrm{CO}_{2}\right.$, carbonates) must first be eliminated by acidifying samples to $\mathrm{pH} 2$ or less to convert inorganic carbon species to $\mathrm{CO}_{2}$. Alternatively, the inorganic carbon interference may be compensated for by separately measuring total carbon (TC) and inorganic carbon (IC). The TOC can be calculated from the difference between TC and IC. There are different methods available for the determination of TOC such as APHA standard 5310 (APHA, 1998) and SFSEN 1484 (SFS-EN 1484, 1997). Nowadays, the TOC analysis is more favourable since its measuring time is quite short (5 to 30 minutes) compared to BOD determination which takes several days before the results are known (Metcalf \& Eddy, 2003). For food industry wastewaters, TOC measurement provides practical information about the water sample because the organic matter content is usually quite high.

\subsection{Nitrogen}

Nitrogen is an important nutrient for microbes and other biological organisms. The chemistry of nitrogen is complex, because of the existence of several oxidation states in the element. The most common and important forms of nitrogen in wastewater are ammonia $\left(\mathrm{NH}_{3}\right)$, ammonium $\left(\mathrm{NH}_{4}{ }^{+}\right)$, nitrogen gas $\left(\mathrm{N}_{2}\right)$, nitrite ion $\left(\mathrm{NO}_{2}{ }^{-}\right)$and nitrate ion $\left(\mathrm{NO}_{3}{ }^{-}\right)$. Overall, total nitrogen $\mathrm{N}_{\text {tot }}$ in wastewater is composed of organic nitrogen, ammonia, nitrite and nitrate. Organic nitrogen is determined using the Kjeldahl method (APHA, 1998) where the aqueous sample is first boiled to remove any ammonia, and then wet combusted. During wet combustion, the organic nitrogen is converted to ammonium. In aqueous solution, ammonia nitrogen exists as either ammonia gas or ammonium ion, depending on the $\mathrm{pH}$ of the solution according to the equilibrium reaction:

$$
\mathrm{NH}_{3}+\mathrm{H}_{2} \mathrm{O} \leftrightarrow \mathrm{NH}_{4}^{+}+\mathrm{OH}^{-}
$$

At $\mathrm{pH} 7$, over $98 \%$ of the ammonia nitrogen is ammonium ion and when the $\mathrm{pH}$ is increased, the equilibrium is displaced to the left. Ammonia is determined by raising the $\mathrm{pH}$, distilling off the ammonia with the steam produced during sample boiling, and condensing the steam which absorbs the gaseous ammonia. The measurement can be made colourimetrically, titrimetrically or with specific ion electrodes (APHA, 1998).

Nitrite nitrogen is determined colourimetrically (APHA, 1998). It is relatively unstable and is easily oxidised to the nitrate. The amount of nitrite in wastewaters is seldom above $1 \mathrm{mg}$ $\mathrm{L}^{-1}$. Although present in low concentration, it is important to determine the amount of nitrite because of its extreme toxicity to most fish and other aquatic species (Metcalf \& Eddy, 2003). Nitrate nitrogen, which can also be determined colourimetrically (APHA, 1998), is the most oxidised form of nitrogen found in wastewaters. The typical range (as nitrogen) detected in wastewaters is from 15 to $20 \mathrm{mg} \mathrm{L}^{-1}$ (Metcalf \& Eddy, 2003).

Ammonium nitrogen, also found in wastewater, can oxidise microbiologically in to a nitrate form (nitrification) and consumes vital oxygen in water systems. The nitrification consumes a relative high amount of oxygen: $1 \mathrm{~g}$ ammonium nitrogen needs $4.3 \mathrm{~g}$ oxygen for the oxidation process, a reason why ammonium nitrogen has to be converted to nitrate and for the removal of total nitrogen from wastewaters before discharging in to the watercourse (Metcalf \& Eddy, 2003). 
In food industry wastewaters, the amount of nitrogen is typically bigger than the amount of phosphorus whilst the total nitrogen content can be even ten folds compared with municipal wastewater (Finnish Food and Drink Industries'Federation, 2005). In slaughterhouse and meat industry wastewaters, for example the decomposition of proteins raises the amount of nitrogen in the effluent (Hiisvirta, 1976).

\subsection{Phosphorus}

Phosphorus is also an essential nutrient to the growth of biological organisms. Due to noxious algal blooms occurring in surface waters, domestic and industrial waste discharges may contain 1 - $2 \mathrm{mg} \mathrm{L}^{-1}$ of phosphorus (P) (Metcalf \& Eddy, 2003).

The usual forms of phosphorus found in aqueous solutions include orthophosphate (e.g. $\mathrm{PO}_{4}^{3-}, \mathrm{HPO}_{3}{ }^{2-}, \mathrm{H}_{2} \mathrm{PO}_{4}^{-}$, and $\mathrm{H}_{3} \mathrm{PO}_{4}$ ), condensed phosphates (pyro-, meta-, and other polyphosphates) and organic phosphate. Phosphorus analyses include the conversion of a phosphorus form to dissolved orthophosphate and the colourimetric determination of this dissolved orthophosphate. Orthophosphate can be determined directly by adding an ammonium molybdate (forming a coloured complex), while condensed and organic phosphates must first be converted to orthophosphates by digestion before being determined as an orthophosphate (APHA, 1998).

In food industry wastewaters, phosphorus occurs as an organic phosphate that originates from proteins and some detergents used by machine washing which may contain phosphorus. However, the nitrogen content of food industry wastewaters is more significant than phosphorus (Hiisvirta, 1976).

\subsection{Odours}

Unpleasant odours in food industry wastewater are usually caused by gases produced by anaerobic decomposition of organic matter. The most common odour causing compound is hydrogen sulphide whose characteristic odour is that of rotten eggs (Metcalf \& Eddy, 2003).

Sulphur is required in the synthesis of proteins and is released in to the degradation process. Under anaerobic conditions, sulphate is reduced biologically to sulphide which can further combine with hydrogen forming hydrogen sulphide $\left(\mathrm{H}_{2} \mathrm{~S}\right)$. This gas is readily soluble in water, colourless and inflammable, but also toxic. Although hydrogen sulphide is the most common gas formed during the anaerobic decomposition of organic matter when considering odours, other volatile compounds, such as indole, skatole and mercaptans, may cause odours far more unpleasant than $\mathrm{H}_{2} \mathrm{~S}$ (Metcalf \& Eddy, 2003).

In recent years, the control of odours has become more important in the designing and operating of wastewater collection, treatment and disposal plants. Odours are the foremost concern of the public in wastewater treatment processes. Quite often, the psychological stress causing by odours is far more important rather than the harm they do to the health of humans (Droste, 1997).

Unpleasant odours are detected by the olfactory system, but which the precise mechanism is not well known. One of the difficulties in developing a global theory has been the insufficient explanation of why compounds with different molecular structures may have similar odours. Nowadays, some agreement has been achieved that the odour of a molecule has to be related to the molecule as a whole. Malodorous compounds in untreated 
wastewater are listed in Table 2. All these compounds can be found or may be developing in wastewaters, depending on ambient conditions (Metcalf \& Eddy, 2003).

\begin{tabular}{lcc}
\hline Odorous compound & Chemical formula & Odour quality \\
\hline Amines & $\mathrm{CH}_{3} \mathrm{NH}_{2},\left(\mathrm{CH}_{3}\right)_{3} \mathrm{NH}$ & Fishy \\
Ammonia & $\mathrm{NH}_{3}$ & Ammonia \\
Diamines & $\mathrm{NH}_{2}\left(\mathrm{CH}_{2}\right)_{4} \mathrm{NH}_{2}$, & Dead body \\
Hydrogen sulphide & $\mathrm{NH}_{2}\left(\mathrm{CH}_{2}\right)_{5} \mathrm{NH}_{2}$ & Rotten eggs \\
Mercaptans (1-2 carbon) & $\mathrm{H}_{2} \mathrm{~S}$ & Decayed cabbage \\
Mercaptans (over 2 carbon) & $\mathrm{CH}_{3} \mathrm{SH}, \mathrm{CH}_{3}\left(\mathrm{CH}_{2}\right) \mathrm{SH}$ & Skunk \\
Organic sulphides & $\left(\mathrm{CH}_{3}\right)_{3} \mathrm{CSH}_{1}$ & Rotten cabbage \\
Skatole & $\mathrm{CH}_{3}\left(\mathrm{CH}_{2}\right)_{3} \mathrm{SH}$ & Faecal matter \\
\hline
\end{tabular}

Table 2. Malodorous compounds in untreated wastewater (Metcalf \& Eddy, 2003).

In the complete characterisation of odour, four independent factors can be classified: intensity, character, hedonics and detectability. Odours can be measured by sensory methods and a specific odorant concentration can be measure by instrumental methods, such as GC-MS analysis (Metcalf \& Eddy, 2003). In the sensory method, a panel of human subjects is exposed to odour-free air diluted odours and the minimum detectable threshold odour concentration (MDTOC) is noted. This procedure can be performed according to the Standard Method 2150B Threshold Odour Test (APHA, 1998).

\section{Advanced oxidation processes}

When selecting the most suitable wastewater treatment method for the specific effluent, both the feasibility of the treatment as well as the economics of the process need to be considered. There are multiplicities of different kinds of techniques available such as physical, chemical and biological wastewater treatments and their combinations.

Advanced oxidation processes (AOPs) belong to the chemical treatment category and are used to oxidise organic compounds found in wastewater which are difficult to handle biologically into simpler end products. Advanced oxidation processes involve the generation of free hydroxyl radical $\left(\mathrm{HO}^{*}\right)$, a powerful, non-selective chemical oxidant (Table 3) (Munter, 2001).

\begin{tabular}{|c|c|}
\hline Oxidising agent & Relative oxidation activity \\
\hline Positively charged hole on titanium dioxide, $\mathrm{TiO}_{2}{ }^{+}$ & 2.35 \\
\hline Hydroxyl radical & 2.05 \\
\hline Atomic oxygen & 1.78 \\
\hline Ozone & 1.52 \\
\hline Hydrogen peroxide & 1.31 \\
\hline Permanganate & 1.24 \\
\hline Hypochlorous acid & 1.10 \\
\hline Chlorine & 1.00 \\
\hline
\end{tabular}

Table 3. Relative oxidation activity of some oxidising agents (Munter, 2001). 


\begin{tabular}{lcc}
\hline \multirow{2}{*}{ Organic compound } & \multicolumn{2}{c}{ Rate constant $\left.\mathbf{M}^{-1} \mathbf{~ s}^{-1}\right]$} \\
\cline { 2 - 3 } & $\mathbf{O}_{3}$ & HO \\
\hline Alcohols & $10^{-2}-1$ & $10^{8}-10^{9}$ \\
Aromatics & $1-10^{2}$ & $10^{8}-10^{10}$ \\
Chlorinated alkenes & $10^{3}-10^{4}$ & $10^{9}-10^{11}$ \\
Ketones & 1 & $10^{9}-10^{10}$ \\
N-containing organics & $10-10^{2}$ & $10^{8}-10^{10}$ \\
Phenols & $10^{3}$ & $10^{9}-10^{10}$ \\
\hline
\end{tabular}

Table 4. Reaction rate constants for ozone and hydroxyl radical for organic compounds (Munter, 2001).

Hydroxyl radical is one of the most active oxidising agents known. It acts very rapidly with most organic molecules with rate constants in the order of $10^{8}-10^{11} \mathrm{M}^{-1} \mathrm{~s}^{-1}$ (Table 4) (Munter, 2001). Depending upon the nature of the organic species, generated hydroxyl radical can attack organic radicals by radical addition, hydrogen abstraction, electron transfer and radical combination.

Radical addition. Reaction of the hydroxyl radical and unsaturated or aliphatic organic compound produces organic radical which can further oxidise by oxygen or ferrous iron to form stable oxidised end products.

$$
\mathrm{R}+\mathrm{HO} \rightarrow \mathrm{ROH}
$$

Hydrogen abstraction. Generated hydroxyl radical can be used to remove hydrogen from an organic compound forming an organic radical and initiating a chain reaction where the organic radical reacts with oxygen. This produces a peroxyl radical, which can react with another organic compound, and so on.

$$
\mathrm{R}+\mathrm{HO} \rightarrow \mathrm{R}+\mathrm{H}_{2} \mathrm{O}
$$

Electron transfer. Electron transfer results in the formation of ions with a higher valence. Oxidation of a monoatomic negative ion will result in the formation of an atom or a free radical.

$$
\mathrm{R}^{\mathrm{n}}+\mathrm{HO} \rightarrow \mathrm{R}^{\mathrm{n}-1}+\mathrm{HO}^{-}
$$

Radical combination. Two radicals form a stable product.

$$
\mathrm{HO}^{\circ}+\mathrm{HO}^{\circ} \rightarrow \mathrm{H}_{2} \mathrm{O}_{2}
$$

Generally, the reaction of hydroxyl radicals and organic compounds will produce water, carbon dioxide and salts (SES, 1994). However, the attack of the HO radical, in the presence of oxygen, generates a complex series of oxidation reactions in which the exact routes of these reactions to complete mineralisation of the organics are still not quite clear. Chlorine containing organic compounds, for example, are oxidised first to intermediates, such as aldehydes and carboxylic acids, and finally to carbon dioxide and water, and to chlorine ions (Munter, 2001).

A very important point, which has to be considered in the case of natural waters, is the presence of carbonates. Efficient trapping of $\mathrm{HO}$ radicals by bicarbonate (equation 6) and 
carbonate (equation 7), radical scavengers, can significantly reduce the efficiency of the abatement of pollutants.

$$
\begin{gathered}
\mathrm{HO}+\mathrm{HCO}_{3}^{-} \rightarrow \mathrm{H}_{2} \mathrm{O}+\mathrm{CO}_{3}^{--} \\
\mathrm{HO}+\mathrm{CO}_{3}^{2-} \rightarrow \mathrm{HO}^{-}+\mathrm{CO}_{3}^{--}
\end{gathered}
$$

However, the generated carbonate radical anion is also an oxidant itself, but its oxidation power is less positive compared to a HO radical (Legrini et al, 1993).

The destruction rate of contaminants is approximately proportional to a constant rate for the pollutant with a $\mathrm{HO}^{\circ}$ radical. As we can see from Table 4, chlorinated alkenes decompose fastest because the double bond is very prone to a hydroxyl attack. Saturated molecules, such as alkanes, are more difficult to oxidise because of a slower reaction rate (Table 4). The powerfulness of the hydroxyl radical gives advanced oxidation processes the ability to achieve oxidative destruction of compounds refractory to conventional hydrogen peroxide or ozone oxidation. AOPs have been used successfully for example, destroying pesticides by photochemical degradation $\left(\mathrm{UV} / \mathrm{O}_{3}\right.$ and $\left.\mathrm{UV} / \mathrm{H}_{2} \mathrm{O}_{2}\right)$ (Andreozzi et al., 2003), photocatalysis $\left(\mathrm{TiO}_{2} / \mathrm{UV}\right.$, Fenton and photo-Fenton process) (Legrini et al., 1993; Fallman et al., 1999) and chemical oxidation processes $\left(\mathrm{O}_{3}, \mathrm{O}_{3} / \mathrm{H}_{2} \mathrm{O}_{2}\right.$ and $\left.\mathrm{H}_{2} \mathrm{O}_{2} / \mathrm{Fe}^{2+}\right)$ (Masten \& Davies, 1994; Benitez et al., 2002), decomposing of organics from textile wastewater, such as surfactants and dyes, by photo-Fenton and $\mathrm{H}_{2} \mathrm{O}_{2}$ /UV-C treatment (García-Montaño et al., 2006), photocatalysis with immobilised $\mathrm{TiO}_{2}$ (Harrelkas et al., 2008) and also for the destruction of organics in different kind of effluents, such as paper mill wastewaters by photocatalysis (Pérez et al., 2001), landfill leachates by the Fenton process (Lopez et al, 2004; Gotvajn et al., 2009 ), olive mill wastewaters by wet air oxidation (Gomes et al., 2007) etc.

Advanced oxidation methods can be split into "cold" and "hot" oxidation. Cold oxidation methods work near to ambient temperature and pressure compared to hot oxidation at elevated temperatures and pressure (Verenich, 2003). Suitable applications of cold oxidation methods include effluents containing relatively small amount of COD $\left(\leq 5.0 \mathrm{~g} \mathrm{~L}^{-1}\right)$. Higher COD contents would require the consumption of large amounts of expensive reactants, such as $\mathrm{O}_{3}$ and $\mathrm{H}_{2} \mathrm{O}_{2}$ (Andreozzi et al., 1999). For wastewaters with higher COD values $\left(\geq 5.0 \mathrm{~g} \mathrm{~L}^{-}\right.$ 1), hot oxidation techniques are more convenient (Mishra et al., 1995).

\subsection{Ozone water processes}

Ozonation at elevated values of $\mathrm{pH}$. Ozone is an effective oxidising agent (Table 3 ) which reacts with most compounds containing multiple bonds, such as $C=C, C=N, N=N$, but not with species containing single bonds (C-C, C-O, O-H) at high rates (Gogate \& Pandit, 2004a). At higher $\mathrm{pH}$ values, ozone reacts almost unselectively with all inorganic and organic compounds present in the solution (Staehelin \& Hoigne, 1982). Rising the $\mathrm{pH}$ of the aqueous solution increases the decomposition rate of the ozone that generates the super-oxide anion radical $\mathrm{O}_{2}{ }^{-}$- and hydroperoxyl radical $\mathrm{HO}_{2}{ }^{\circ}$. For example, the ozonide anion $\mathrm{O}_{3}{ }^{-}$- is formed by the reaction between $\mathrm{O}_{3}$ and $\mathrm{O}_{2}{ }^{\circ}$. The ozonide anion further decomposes to a $\mathrm{HO}^{\circ}$ radical, such that, three ozone molecules will produce two $\mathrm{HO}^{\circ}$ radicals (equation 8) (Munter, 2001):

$$
3 \mathrm{O}_{3}+\mathrm{HO}^{-}+\mathrm{H}^{+} \rightarrow 2 \mathrm{HO}+4 \mathrm{O}_{2}
$$


The rate constants of the hydroxyl radicals are typically $10^{6}-10^{9}$ times higher than the corresponding reaction rate constants of molecular ozone (Table 4). The oxidation of organic compounds may also occur due to the combination of reactions with molecular ozone and reactions with hydroxyl radicals (Munter, 2001).

Ozone with hydrogen peroxide. The addition of hydrogen peroxide to the aqueous solution of ozone enhances the decomposition of $\mathrm{O}_{3}$ with the formation of hydroxyl radicals. To summarise: two ozone molecules will produce two hydroxyl radicals (equation 9) (Munter, 2001):

$$
2 \mathrm{O}_{3}+\mathrm{H}_{2} \mathrm{O}_{2} \rightarrow 2 \mathrm{HO}+3 \mathrm{O}_{2}
$$

The action of both ozone molecules and the generated hydroxyl radicals results in a significant improvement in the rates of decomposition of pollutants in aqueous solutions.

Ozone and catalyst. Catalytic ozonation is another opportunity to accelerate ozonation with compounds which are weakly reactive with ozone, such as atratzine. Several homogeneous catalysts, such as zinc and copper sulfates, silver nitrate, chromium trioxide (Abdo et al., 1988) and also heterogeneous catalysts, $\mathrm{Ru} / \mathrm{CeO}_{2}$, (Delanoë et al., 2001), $\mathrm{MnO}_{2}$ (Ma \& Graham, 1997), $\mathrm{TiO}_{2} / \mathrm{Al}_{2} \mathrm{O}_{3}$ (Beltrán et al., 2004) and $\mathrm{Pt} / \mathrm{Al}_{2} \mathrm{O}_{3}$ (Chang et al., 2009) have been studied. According to these studies, both homogeneous and heterogeneous catalysts are able to improve the efficiency of ozone for the removal of different organic compounds in an aqueous solution.

\subsection{Photolysis}

In a photo-oxidation reaction, UV radiation (photon) excites an electron of an organic molecule $(C)$ from the ground state to the excited state $\left(C^{*}\right)$ (equation 10). The excited organic molecule excites further molecular oxygen (equation 11) with a subsequent recombination of the radical ions or hydrolysis of the radical cation, or homolysis (equation 12) to form radicals which can react with oxygen (equation 13) (Legrini et al., 1993).

$$
\begin{gathered}
\mathrm{C} \stackrel{\mathrm{hv}}{\rightarrow} \mathrm{C}^{*} \\
\mathrm{C}^{*}+\mathrm{O}_{2} \rightarrow \mathrm{C}^{+} \mathrm{O}_{2}^{--} \\
\mathrm{R}-\mathrm{X} \stackrel{\mathrm{hv}}{\rightarrow} \mathrm{R}+\mathrm{X} \\
\mathrm{R}+\mathrm{O}_{2} \rightarrow \mathrm{RO}_{2}
\end{gathered}
$$

The rate of the photo-oxidation reaction depends on the adsorption cross section of the medium, the quantum yield of the process, the photon rate at the wavelength of excitation and the concentration of dissolved molecular oxygen (Legrini et al, 1993). However, to achieve the complete mineralisation of the treated effluent, photolysis is usually combined with oxidising compounds (hydrogen peroxide, ozone) or semiconductors (such as titanium dioxide).

\subsubsection{UV/ozone, $\mathrm{UV} / \mathrm{H}_{2} \mathrm{O}_{2}$ and $\mathrm{UV} / \mathrm{O}_{3} / \mathrm{H}_{2} \mathrm{O}_{2}$ processes}

The combination of UV light and ozone/hydrogen peroxide or both significantly enhances the rate of generating free radicals. Ozone adsorbs UV radiation at a wavelength of $254 \mathrm{~nm}$ 
(equation 14) producing hydrogen peroxide as an intermediate, which decomposes further to hydrogen peroxide radicals (equation 15) (Munter, 2001):

$$
\begin{gathered}
\mathrm{O}_{3}+\mathrm{hv} \rightarrow \mathrm{O}_{2}+\mathrm{O}\left({ }^{1} \mathrm{D}\right) \\
\mathrm{O}\left({ }^{1} \mathrm{D}\right)+\mathrm{H}_{2} \mathrm{O} \rightarrow \mathrm{H}_{2} \mathrm{O}_{2} \rightarrow 2 \mathrm{HO}
\end{gathered}
$$

The mechanism for the photolysis of hydrogen peroxide is the cleavage of the molecule into two hydroxyl radicals (equation 16) (Munter, 2001):

$$
\mathrm{H}_{2} \mathrm{O}_{2} \stackrel{\mathrm{hv}}{\rightarrow} 2 \mathrm{HO}
$$

Depending on the $\mathrm{pH}$ value of the aqueous $\mathrm{H}_{2} \mathrm{O}_{2}$ solution, $\mathrm{HO}_{2}-$ also absorbs $\mathrm{UV}$ radiation at $254 \mathrm{~nm}$ to form a hydroxyl radical (equations 17, 18):

$$
\begin{aligned}
& \mathrm{H}_{2} \mathrm{O}_{2} \leftrightarrow \mathrm{HO}_{2}^{-}+\mathrm{H}^{+} \\
& \mathrm{HO}_{2}^{-} \stackrel{\text { hv }}{\rightarrow}+\mathrm{HO}+\mathrm{O}^{--}
\end{aligned}
$$

The combination of UV photolysis and ozone/hydrogen peroxide will be beneficial only for contaminants which require a relatively higher level of oxidation conditions (higher activation energy) (Gogate \& Pandit, 2004b).

\subsubsection{Photocatalysis}

In the photocatalytic process, semiconductor material (often $\mathrm{TiO}_{2}$ ) is excited by electromagnetic radiation possessing energy of sufficient magnitude, to produce conduction band electrons and valence band holes (equation 19) (Andreozzi et al, 1999):

$$
\mathrm{TiO}_{2} \stackrel{\mathrm{hv}}{\rightarrow} \mathrm{e}^{-}+\mathrm{h}^{+}
$$

Formed electrons can reduce some metals and dissolved oxygen to produce a superoxide radical ion $\mathrm{O}_{2} \cdot$ - (equations 20,21 ):

$$
\begin{aligned}
& \mathrm{M}+\mathrm{e}^{-} \rightarrow \mathrm{O}_{2}^{--} \\
& \mathrm{O}_{2}+\mathrm{e}^{-} \rightarrow \mathrm{O}_{2}^{--}
\end{aligned}
$$

Remaining holes then oxidise and adsorbed $\mathrm{H}_{2} \mathrm{O}$ or $\mathrm{HO}^{-}$to reactive hydroxyl radicals (equations 22, 23):

$$
\begin{gathered}
\mathrm{TiO}_{2}\left(h^{+}\right)+\mathrm{H}_{2} \mathrm{O}_{\mathrm{ad}} \rightarrow \mathrm{TiO}_{2}+\mathrm{HO}_{\mathrm{ad}}+\mathrm{H}^{+} \\
\mathrm{TiO}_{2}\left(\mathrm{~h}^{+}\right)+\mathrm{HO}_{\mathrm{ad}}^{-} \rightarrow \mathrm{TiO}_{2}+\mathrm{HO}_{\mathrm{ad}}
\end{gathered}
$$

Formed hydroxyl radicals may also react with organic compounds in water as described in the equations (2)-(5).

Several catalytic materials have been studied in photocatalysis although $\mathrm{TiO}_{2}$ in the anatase form seems to possess the best photocatalytic performance (Andreozzi et al, 1999). $\mathrm{TiO}_{2}$ in 
its anatase form has an energy bandgap of $3.2 \mathrm{eV}$ and can be activated by UV radiation with a wavelength up to $387.5 \mathrm{~nm}$. Therefore, many researchers have focused on examining the use of sunlight in photocatalytic processes. Unfortunately, only a few percent of solar energy reaches the surface of the earth that could in principle be utilised as a direct exciter to $\mathrm{TiO}_{2}$ (Munter, 2001).

Degussa $\mathrm{P}-25 \mathrm{TiO}_{2}$ catalyst is probably the most active catalyst in photocatalytic reactions however its optimum effective will always be strongly dependent on the type and concentration of the treated pollutant (Gogate \& Pandit, 2004a). In several studies, the doping of $\mathrm{TiO}_{2}$ with metals, such as, platinum (Hufschmidt et al, 2002), silver, zirconium and iron (Kment et al, 2010) as well as, sulphur, carbon and nitrogen (Menendez-Flores et al, 2011; Wang et al, 2011) has been proven to enhance the activity of the catalyst.

\subsection{Fenton processes}

Fenton's reagent consists of $\mathrm{H}_{2} \mathrm{O}_{2}$ and ferrous iron, which generates hydroxyl radicals (equation 24) (Munter, 2001):

$$
\mathrm{Fe}^{2+}+\mathrm{H}_{2} \mathrm{O}_{2} \rightarrow \mathrm{Fe}^{3+}+\mathrm{HO}^{-}+\mathrm{HO}^{\circ}
$$

The generated ferric ion decomposes $\mathrm{H}_{2} \mathrm{O}_{2}$ forming hydroxyl radicals (equations 25, 26):

$$
\begin{gathered}
\mathrm{Fe}^{3+}+\mathrm{H}_{2} \mathrm{O}_{2} \rightarrow \mathrm{H}^{+}+\mathrm{Fe}-\mathrm{OOH}^{2+} \\
\mathrm{Fe}-\mathrm{OOH}^{2+} \rightarrow \mathrm{HO}_{2}+\mathrm{Fe}^{2+}
\end{gathered}
$$

After the reaction (26), the formed ferrous iron again decomposes $\mathrm{H}_{2} \mathrm{O}_{2}$ (24) etc. The hydrogen peroxide decomposition is an iron salt catalyzed reaction and in reactions $(25,26)$ iron is regenerated again to iron(II).

The most important operating parameter in the Fenton process is the $\mathrm{pH}$ of the solution. According to the majority of researchers, the optimum operating $\mathrm{pH}$ to be observed is 3 . However, the Fenton process effectively generates hydroxyl radicals, it consumes one molecule of $\mathrm{Fe}^{2+}$ for each $\mathrm{HO}$ radical produced, which results in a high concentration of Fe(II) (Munter, 2001).

\subsubsection{Photoassisted Fenton processes}

In photoassisted Fenton process, $\mathrm{Fe}^{3+}$ ions are added to the $\mathrm{H}_{2} \mathrm{O}_{2} / \mathrm{UV}$ process. In acidic $\mathrm{pH}$, a $\mathrm{Fe}(\mathrm{OH})^{2+}$ complex is formed (equation 27) (Munter, 2001):

$$
\mathrm{Fe}^{3+}+\mathrm{H}_{2} \mathrm{O} \rightarrow \mathrm{Fe}(\mathrm{OH})^{2+}+\mathrm{H}^{+}
$$

The photolysis of $\mathrm{Fe}^{3+}$ complexes allows $\mathrm{Fe}^{2+}$ regeneration and formation of hydroxyl radicals (equation 28) (Munter, 2001):

$$
\mathrm{Fe}(\mathrm{OH})^{2+} \stackrel{\mathrm{hv}}{\rightarrow} \mathrm{Fe}^{2+}+\mathrm{HO}^{\cdot}
$$

The combination of $\mathrm{H}_{2} \mathrm{O}_{2} / \mathrm{UV}$ and iron salt produces more hydroxyl radicals compared with a conventional Fenton process or photolysis, thus the technique enhances the degradation of treated pollutants (Gogate and Pandit, 2004b). 


\subsubsection{Electro-Fenton processes}

In the Electro-Fenton process, $\mathrm{Fe}^{2+}$ and $\mathrm{H}_{2} \mathrm{O}_{2}$ are generated electrochemically, either separately or concurrently. Hydrogen peroxide can be electrogenated by the reduction of dissolved oxygen (equation 29), and ferrous iron by the reduction of ferric iron (equation 30) or by oxidation of a sacrificial Fe anode (equation 31) (Szpyrkowicz et al., 2001):

$$
\begin{gathered}
\mathrm{O}_{2}+2 \mathrm{H}^{+}+2 \mathrm{e}^{-} \rightarrow \mathrm{H}_{2} \mathrm{O}_{2} \\
\mathrm{Fe}^{3+}+\mathrm{e}^{-} \rightarrow \mathrm{Fe}^{2+} \\
\mathrm{Fe} \rightarrow \mathrm{Fe}^{2+}+2 \mathrm{e}^{-}
\end{gathered}
$$

The reaction between $\mathrm{H}_{2} \mathrm{O}_{2}$ and $\mathrm{Fe}^{2+}$ produces hydroxyl radicals (equation 24).

\subsection{Wet oxidation processes}

The main differences in wet oxidation processes compared with "cold" oxidation techniques described earlier are the operating temperature and pressure. Typically, wet oxidation processes are operating at temperatures from $90{ }^{\circ} \mathrm{C}$ (wet peroxide oxidation) to even over $600{ }^{\circ} \mathrm{C}$ (supercritical wet air oxidation). The operating conditions of different wet oxidation techniques are described in Table 5.

\begin{tabular}{lcccc}
\hline $\begin{array}{l}\text { Operating } \\
\text { parameter }\end{array}$ & $\begin{array}{c}\text { Wet } \\
\text { peroxide } \\
\text { oxidation } \\
\text { (WPO) }\end{array}$ & $\begin{array}{c}\text { Catalytic wet } \\
\text { air oxidation } \\
\text { (CWAO) }\end{array}$ & $\begin{array}{c}\text { Wet air } \\
\text { oxidation } \\
\text { (WAO) }\end{array}$ & $\begin{array}{c}\text { Supercritical wet } \\
\text { air oxidation } \\
\text { (SCWO) }\end{array}$ \\
\hline $\begin{array}{l}\text { Temperature }\left[{ }^{\circ} \mathrm{C}\right] \\
\text { Pressure }[\mathrm{bar}]\end{array}$ & $100-140$ & $130-250$ & $125-320$ & $>374$ \\
\hline
\end{tabular}

Table 5. Operating conditions of different wet oxidation techniques (Debellefontaine et al., 1996; Mishra et al., 1995).

The wet oxidation processes are suitable for wastewaters and sludges which are both too diluted to incinerate and too concentrated for biological treatment. The COD level of the wastes appropriate to be treated by WAO techniques is typically between 5 and $200 \mathrm{~g} \mathrm{~L}^{-1}$ (Kolaczkowski et al., 1999).

\subsubsection{Wet peroxide oxidation}

WPO process is adapted from the Fenton process (Section 3.3) but it operates at temperatures above $100{ }^{\circ} \mathrm{C}$. The oxidation mechanism is the same as for the Fenton's reaction (equations 24-26), but as a consequence of a higher operating temperature more efficient TOC removal can be obtained (Debellefontaine et al., 1996). A typical catalyst in the WPO is iron but other catalytic materials have also been used successfully in the process such as copper (Caudo et al, 2008), activated carbon (Gomes et al., 2010), ruthenium (Rokhina et al., 2010) etc.

\subsubsection{Wet air oxidation}

In the WAO process organic and oxidisable inorganic compounds of the liquid phase are oxidised at elevated temperatures and pressures (Table 5) using oxygen containing gas (air, 
molecular oxygen) to intermediates (short-chain organic molecules), $\mathrm{CO}_{2}$ and water. The degree of oxidation is dependent on temperature, oxygen partial pressure, operating time and, of course, the oxidisability of the compounds under consideration. To summarise, it can be said that, the higher the operating temperature the higher is the extent of oxidation achieved (Mishra et al. 1995).

According to Lixiong et al. (1991) the WAO reaction starts with the reaction of oxygen and the weakest $\mathrm{C}-\mathrm{H}$ bonds of the oxidised organic compound ( $\mathrm{R}$ denotes the organic functional group) forming free radicals:

$$
\mathrm{RH}+\mathrm{O}_{2} \rightarrow \mathrm{R}+\mathrm{HO}_{2}
$$

More organic radicals are formed with the reaction of $\mathrm{HO}_{2}$ and organic molecule:

$$
\mathrm{RH}+\mathrm{HO}_{2} \rightarrow \mathrm{R}+\mathrm{H}_{2} \mathrm{O}_{2}
$$

At the high operating temperature of $\mathrm{WAO}, \mathrm{H}_{2} \mathrm{O}_{2}$ decomposes rapidly in the homogeneous or heterogeneous species (term $\mathrm{M}$ ) to hydroxyl radicals:

$$
\mathrm{H}_{2} \mathrm{O}_{2}+\mathrm{M} \rightarrow 2 \mathrm{HO}+\mathrm{M}
$$

The chain reaction continues with the oxidation of organic compounds by hydroxyl radicals following a hydrogen abstraction mechanism described earlier (equation 3).

\subsubsection{Catalytic wet air oxidation}

Compared with conventional WAO, catalytic wet air oxidation (CWAO) has lower energy requirements. Due to the presence of homogeneous or heterogeneous catalysts, lower operating conditions (air/oxygen pressure and temperature) can be used to achieve much higher oxidation rates. Various heterogeneous catalysts have been synthesised and tested in CWAO reactions, based either on metal oxides or supported noble metals (Levec \& Pintar, 2007). Mixtures of metal oxides such as $\mathrm{Cu}, \mathrm{Zn}$, Co and $\mathrm{Al}$, are reported to exhibit good activity, but leaching of these metals has been detected (Mantzavinos et al., 1996a). Supported noble metal catalysts, such as $\mathrm{Pt}, \mathrm{Pd}, \mathrm{Rh}, \mathrm{Re}, \mathrm{Ru}$ on $\mathrm{Al}_{2} \mathrm{O}_{3}$ (Mantzavinos et al., 1996b) and ceria including doped-ceria supported Pt and Ru (Keav et al., 2010) are less prone to leaching and are also more effective for oxidising organic compounds than metal oxide catalysts. CWAO processes have also been commercialised. In Japan, several companies have developed catalytic wet air oxidation technologies relying on heterogeneous supported noble metal catalysts (Harada et al., 1987; Ishii et al., 1994). In Europe, homogeneous CWAO processes such as Ciba-Geigy, LOPROX, ORCAN and ATHOS have already been developed in the 1990s (Luck, 1999).

\subsubsection{Supercritical wet air oxidation}

In a supercritical water oxidation process the reaction temperature is above $374{ }^{\circ} \mathrm{C}$ and the oxygen containing gas is at a pressure of 221 bar, which is the critical point of water. Above this critical point, water is an excellent solvent for both organic compounds and gases; therefore oxidisable compounds and oxygen can be mixed in a single homogeneous phase. This is the great advantage of supercritical water oxidation and in general, the destruction efficiencies of pollutants are in the order of $99-99.9 \%$ at $400-500{ }^{\circ} \mathrm{C}$ for a residence time interval of 1-5 minutes (Mishra et al., 1995). 


\section{AOP applications in food industry wastewater treatment}

Food industry wastewaters can generally be treated biologically, in both aerobic and anaerobic reactors. However, as a consequence of diverse consumption, the forming effluents may contain compounds which are poisonous to the micro-organisms in the biological treatment plant. The pre-treatment of the effluent by chemical oxidation, especially with AOPs, can oxidise biorefractory pollutants into a more easily biodegradably form. In the following Sections, there are several examples of AOP applications in different sectors of food industry wastewater treatment.

\subsection{Winery and distillery wastewater}

The winery industry generates strong organic wastewater whose quality is highly dependent on the production activities. A typical COD value of the effluent containing sugars, ethanol, organic acids, aldehydes, other microbial fermentation products, soaps and detergents, is between 800 and $1200 \mathrm{mg} \mathrm{L}^{-1}$ but can easily increase to over $25000 \mathrm{mg} \mathrm{L}^{-1}$. Winery wastewater is quite acidic ( $\mathrm{pH} 3-4)$ and it usually contains large amounts of phosphorus, but not nitrogen and other trace minerals, which are important for biological treatment (Oller et al., 2010).

There are some studies that have considered the ozonation of winery wastewaters. Lucas et al. (2009a) for example, have treated winery wastewaters by ozonation in a bubble column reactor. During a three hour reaction period the degradation of aromatic and polyphenol content was found to be significant, thus the biodegradability of the wastewater was improved and therefore the ozonation may be considered as pre-treatment to further biological treatment. In addition, Beltrán et al. (1999) have noticed the same BOD/COD enhancement in winery effluent after ozonation whereas Lucas et al. (2010) have combined $\mathrm{UV}$ and $\mathrm{UV} / \mathrm{H}_{2} \mathrm{O}_{2}$ with ozone. According to the results, $\mathrm{O}_{3} / \mathrm{UV} / \mathrm{H}_{2} \mathrm{O}_{2}$ combination was identified as the most economical process compared with $\mathrm{O}_{3}$ and $\mathrm{O}_{3} / \mathrm{UV}$ to the treated winery wastewater.

Winery wastewaters were also treated by solar photo-Fenton integrated with activated sludge treatment in a pilot-plant scale (Mosteo et. al., 2008) and by $\mathrm{UV}$ and $\mathrm{UV} / \mathrm{TiO}_{2}$ at labscale (Agustina et. al., 2008). With both techniques the efficient removal of organics was successfully achieved whereas photo-Fenton combined with biological treatment showed higher mineralisation rates and a significant toxicity decrease of the treated effluent.

Sources of distillery wastewater, much in common with winery wastewater, are stillage, fermenter and condenser cooling water, and fermenter wastewater. These effluents contain high concentrations of organic material (COD 100-150 $\mathrm{g} \mathrm{L}^{-1}$ and BOD 40-200 $\mathrm{g} \mathrm{L}^{-1}$ ) and fertilisers such as potassium, phosphorus and nitrogen. In addition, the molasses wastewater from ethanol fermentation has a typical brown colour which is difficult to remove by traditional biological treatment (Oller et al., 2010).

Several AOP methods have been studied in the treatment of distillery wastewaters. Beltrán et al. (1997b), Benitez et al. (1999; 2003), Sangave et al. (2007) and Sreethawong \& Chavadej (2008) have all used ozonation and its combination with $\mathrm{UV}, \mathrm{H}_{2} \mathrm{O}_{2}$ or Fe-catalyst in the degradation of organics from distillery wastewaters. All these researchers agree that the removal of organic matter improved with the simultaneous presence of UV radiation, hydrogen peroxide or Fe-catalyst in addition to ozone, due to the contribution of hydroxyl radicals generated in these combined processes. In addition, the combined process of ozone 
pre-treatment followed by an activated sludge step provides enhancement in the removal of substrate obtained in relation to that obtained in the single aerobic treatment without ozonation, i.e. from $28 \%$ to $39 \%$ (Benitez et al., 1999; 2003). The integrated process (ozone pre-treatment-aerobic biological oxidation-ozone post-treatment) achieved almost $80 \%$ COD reduction in the treatment of distillery wastewater along with the decolouration of the effluent compared with 35\% COD removal for non-ozonated samples (Sangave et al., 2007).

$\mathrm{UV} / \mathrm{H}_{2} \mathrm{O}_{2}$ (Beltrán et al., 1997a) and electro-Fenton (Yavuz, 2007) processes have also been used for the treatment of distillery wastewaters. The EF process (Yavuz, 2007) seems to be a promising technique with the COD removal over $90 \%$ compared with a UV radiation and hydrogen peroxide combination whose COD reduction is only 38\% (Beltrán et al., 1997a).

Belkacemi et al. $(1999 ; 2000)$ investigated wet oxidation and catalytic wet oxidation for the removal of organics from distillery liquors. The initial TOC of the effluent was $22500 \mathrm{mg} \mathrm{L}^{-1}$ while in the AOPs described earlier the total organic carbon was 10 or even 100 times lower. In the temperature and oxygen partial ranges of $180-250{ }^{\circ} \mathrm{C}$ and $5-25$ bar respectively, the highest TOC removal (around 60\%) was achieved with $\mathrm{Mn} / \mathrm{Ce}$ oxides and $\mathrm{Cu}$ (II)NaY catalysts. These catalysts were found to be very effective for short contact times, while for prolonged exposures catalysts deactivation by fouling carbonaceous deposit was shown to be the prime factor responsible for the loss of catalysts activity (Belkacemi et al., 2000). In the supercritical water oxidation of alcohol distillery wastewater (Goto et al., 1998) almost complete colour, odour and TOC removal was attained when more than stoichiometric amount (over $100 \%$ ) of oxidant $\left(\mathrm{H}_{2} \mathrm{O}_{2}\right)$ was used in temperatures between $200-600{ }^{\circ} \mathrm{C}$.

\subsection{Olive industry wastewater}

Wastewaters from olive oil extraction plants, also called olive mill wastewaters, and wastewaters generated by table olive production, contain high concentration of phenolic compounds. In olive oil production, an oily juice is extracted from the fruit through milling or centrifugation. Table olive production requires the same treatment in order to eliminate the bitterness of the fruit, due to the presence of polyphenolic compounds (Bautista et al., 2008).

Olive mill wastewater contains polysaccharides, sugars, polyphenols, polyalcohols, proteins, organic acids, oil etc. and therefore, the COD of the effluent may be as high as 220 $\mathrm{g} \mathrm{L}^{-1}$ and even $190 \mathrm{~g} \mathrm{~L}^{-1}$ for the amount of suspended solids (Oller et al., 2010).

For several years, olive mill wastewater has been the most polluting and troublesome waste produced by olive mills in all the countries surrounding the Mediterranean. Thus, the management of this liquid residue has been investigated extensively and the efficiency of AOPs for treating olive mill effluents has been studied widely (Mantzavinos \& Kalogerakis, 2005). Many researchers have also investigated Fenton processes in the treatment of olive mill effluents (Table 6).

Olive mill wastewater has also been treated by several other AOPs such as ozonation or ozone/UV (Lafi et al., 2009) which have increased the biodegradability of the effluent. Minh et al. (2008) and Gomes et al. (2007) have been successful in decreasing the TOC and phenolic content of olive mill wastewater by CWAO. At reaction conditions of $190{ }^{\circ} \mathrm{C}$ and 70 bar of air using $\mathrm{Pt}$ and $\mathrm{Ru}$ supported on titania and zirconia carriers, the toxicity and phytotoxicity of the effluent decreased to a suitable level for anaerobic treatment (Minh et al., 2008). Gomes et al. (2007) reported that with the carbon supported Pt catalyst TOC and the colour of olive mill wastewater were completely removed after $8 \mathrm{~h}$ of reaction at $200{ }^{\circ} \mathrm{C}$ 
at 6.9 bar of $\mathrm{O}_{2}$. Caudo et al. (2008) have also tested copper-pillared clays as catalysts in wet hydrogen peroxide catalytic oxidation (WHPCO) of olive mill wastewater. According to the research, copper pillared clays are effective and stable catalysts for WHPCO of wastes in water whilst this treatment decreases the toxicity of the olive mill wastewater.

\begin{tabular}{|c|c|c|}
\hline Fenton process & Conclusions & References \\
\hline \multirow[t]{4}{*}{ Fenton } & $\begin{array}{c}\text { COD removal } 80-90 \% \text {, followed by biological } \\
\text { treatment }\end{array}$ & $\begin{array}{l}\text { Bressan et al. } \\
(2004)\end{array}$ \\
\hline & COD and aromatics removal $40 \%$ & $\begin{array}{l}\text { Ahmadi et al. } \\
\text { (2005) }\end{array}$ \\
\hline & $\begin{array}{l}\text { Considered as a pre-treatment (COD removal 40- } \\
\qquad 50 \%)\end{array}$ & $\begin{array}{l}\text { Dogruel et al. } \\
\qquad(2009)\end{array}$ \\
\hline & COD removal $70 \%$ & $\begin{array}{c}\text { Lucas \& } \\
\text { Peres }(2009 b)\end{array}$ \\
\hline $\begin{array}{l}\text { Coagulation and } \\
\text { Fenton/photo- } \\
\text { Fenton }\end{array}$ & COD removal $85 \%$ by $\mathrm{F}$ and $95 \%$ by $\mathrm{PF}$ & $\begin{array}{l}\text { Rizzo et al. } \\
\qquad(2008)\end{array}$ \\
\hline $\begin{array}{l}\text { Coagulation- } \\
\text { flocculation-Fenton }\end{array}$ & COD removal $60 \%$ and decrease of phytotoxicity & $\begin{array}{l}\text { Ginos et al. } \\
\text { (2006) }\end{array}$ \\
\hline $\begin{array}{l}\text { Fenton with zero- } \\
\text { valent iron }\end{array}$ & $\begin{array}{c}\text { Considered as a pre-treatment (COD removal 75- } \\
20 \% \text { ) before classical biological process }\end{array}$ & $\begin{array}{l}\text { Kallel et al. } \\
\qquad(2009)\end{array}$ \\
\hline Solar photo-Fenton & $\begin{array}{c}\text { COD removal } 85 \% \text {, phenolic compounds } \\
\text { degradation even } 100 \%\end{array}$ & $\begin{array}{l}\text { Gernjak et al. } \\
\quad(2004)\end{array}$ \\
\hline \multirow[t]{2}{*}{ Electro-Fenton } & $\begin{array}{c}\text { Considered as a pre-treatment (COD removal } \\
66 \% \text { ) before anaerobic digestion }\end{array}$ & $\begin{array}{l}\text { Khoufi et al. } \\
\qquad(2006)\end{array}$ \\
\hline & $\begin{array}{l}\text { Considered as a pre-treatment (COD removal } \\
53 \% \text { ) before anaerobic digestion and } \\
\text { ultrafiltration resulting in a complete detoxify of } \\
\text { effluent. Pilot plant. }\end{array}$ & $\begin{array}{l}\text { Khoufi et al. } \\
\qquad(2009)\end{array}$ \\
\hline
\end{tabular}

Table 6. Fenton processes for the treatment of olive mill wastewater.

The organic content of wastewater from a table olive process is quite similar to olive mill wastewater containing phenols, polyphenols, sugars, acids, tannins, pectins and oil residues, with a COD of several grams per litre. The inorganic fraction consists of high concentrations of $\mathrm{NaCl}$ and $\mathrm{NaOH}$ which are used for debittering and fermentation, as well as trace amounts of various metals. As a consequence of the complexity of these effluents, they are unsuitable for conventional aerobic and anaerobic processes (Oller et al., 2010). Recently, it has been possible to enhance the biodegradability of the table olive processing wastewater by different AOPs. Kyriacou et al. (2005) have scaled this treatment method up from a labscale to a pilot-scale for green table olive processing wastewater, which combines biological treatment with an electro-Fenton system. In the pilot plant, 75\% COD removal was achieved and the post-treatment by coagulation finally gave an overall $98 \%$ COD removal for the treated effluent. Photocatalytic treatment and WAO alone (Chatzisymeon et al., 2008; Katsoni et al., 2008) as well as $\mathrm{O}_{3}, \mathrm{O}_{3} / \mathrm{H}_{2} \mathrm{O}_{2}, \mathrm{O}_{3} / \mathrm{UV}, \mathrm{UV}, \mathrm{UV} / \mathrm{H}_{2} \mathrm{O}_{2}$, Fenton, photo-Fenton and WAO processes combined with aerobic biological treatment have been studied for 
organic matter removal from table olive processing wastewaters (Beltran-Heredia et al., 2000; Benitez et al., 2001a, b; Rivas et al., 2000, 2001).

\subsection{Meat processing industry wastewater}

Meat processing industry wastewaters constitute one of the greatest concerns of the agroindustrial sector, as approximately $62 \mathrm{Mm}^{3}$ /year of water is used worldwide. However, only a small amount of this becomes a component of the final product. Meat processing industry wastewater contains high concentrations of fat, dry waste, sediments and total suspended matter as well as nitrogen and chlorides whilst possessing high biological and chemical oxygen demand (Sroka et al., 2004). Traditionally, meat processing industry wastewaters are treated by anaerobic or aerobic biological systems (Johns, 1995) but recently few studies concerning AOPs have been published. In the publication of Sena et al (2009), dissolved air flotation (DAF) followed by photo-peroxidation $\left(\mathrm{UV} / \mathrm{H}_{2} \mathrm{O}_{2}\right.$ ) and photo-Fenton reactions were evaluated in the treatment of meat processing industry wastewater. According to the results, DAF connected with photo-Fenton treatment achieved the best removals of COD, colour, turbidity and total solids of the treated effluent. WAO have also been used for the removal of organic compounds from meat processing industry wastewater (Heponiemi et al., 2009). After catalytic wet air oxidation treatment, the biodegradability of the wastewater sample has improved.

\subsection{Vegetable and fruit processing wastewater}

Various factors, such as seasonal and source variations, unit operations etc. affect the composition of vegetable and fruit processing industry wastewater. Typically, this effluent contains high organic loads, e.g. from peeling and blanching, cleaning agents and suspended solids such as fibres, dissolved solids, salts, nutrients etc. Furthermore, residual pesticides, which are difficult to degrade during wastewater treatment, may be a concern (EC, 2006). In some studies, AOPs have been used for the removal of organics from fruit and vegetable processing industry wastewaters. In the research of Beltran et al. (1997a, b), wastewater from a tomato processing plant was treated by $\mathrm{UV}, \mathrm{UV} / \mathrm{H}_{2} \mathrm{O}_{2}, \mathrm{O}_{3}, \mathrm{O}_{3} / \mathrm{H}_{2} \mathrm{O}_{2}$ and $\mathrm{O}_{3} / \mathrm{UV}$. According to results, an ozone-UV radiation system achieved the highest degradation rates (90\% removal of COD). Due to the improved biodegradability of the treated effluent, Beltran et al. (1997a, b) recommended the combination of this process with biological oxidation. Caudo et al. (2008) have studied copper-pillared clays catalysed wet peroxide oxidation of citrus juice production wastewater. This effluent contains various phenolic compounds with a chemical oxygen demand of over $4000 \mathrm{mg} \mathrm{L}^{-1}$. After $4 \mathrm{~h}$ of oxidation reaction, the TOC had decreased $50 \%$ and the biodegradability of the effluent $\left(\mathrm{BOD}_{5} / \mathrm{COD}\right.$ index) had increased from 0.05 to 0.4 .

\subsection{Miscellaneous wastewater}

Coffee industry wastewater is another example of a highly polluted food industry wastewater. The coffee industry uses large amounts (around 40-45 L per kilogram of coffee) of water during the various stages of the production process. The forming effluent contains e.g. caffeine, fat and peptic substances, as well as many different macromolecules such as lignins, tannins and humic acids, which are difficult to handle by conventional biological treatment processes. Recently, Zayas et al. (2007) studied the combination of the chemical 
coagulation-flocculation process with various advanced oxidation processes $\left(\mathrm{UV} / \mathrm{H}_{2} \mathrm{O}_{2}\right.$, $\mathrm{UV} / \mathrm{O}_{3}, \mathrm{UV} / \mathrm{H}_{2} \mathrm{O}_{2} / \mathrm{O}_{3}$ ) for the treatment of coffee industry wastewater. Among the AOPs tested, $\mathrm{UV} / \mathrm{H}_{2} \mathrm{O}_{2} / \mathrm{O}_{3}$ process was the most effective in the reduction of COD, colour and turbidity of the treated effluent.

Baker's yeast is a commercial product of molasses (the end product of sugar manufacture) which constitutes a solution of sugar, organic and inorganic material in water. Baker's yeast industry wastewater has a high BOD and COD values which contains significant amount of nitrogen and non-biodegradable organic pollutants. In addition, the effluent has a typical dark colour and, therefore the possible decolourisation of the effluent has been investigated by the Fenton process (Pala \& Erden, 2005). Fenton oxidation was applied to the biologically pre-treated baker's yeast industry wastewater. In the optimum operating conditions, $99 \%$ colour removal and $88 \%$ COD reduction was achieved. Photo-Fenton and $\mathrm{UV} / \mathrm{H}_{2} \mathrm{O}_{2}$ processes have also been studied in the removal of colour and organics from baker's yeast effluents (Çatalkaya \& Şengül, 2006).

Palm oil effluent is a colloidal dispersion of biological origin which has a typical unpleasant odour. The total solids content of the effluent is $5-7 \%$ and it constitutes of dissolved, organic and inorganic solids, a reason why it is extremely difficult to treat by conventional wastewater treatment methods (Zinatizadeh et al., 2006). In the study of Babu et al. (2010) a palm oil effluent was treated by a combined electro-Fenton-biological oxidation process. After $2 \mathrm{~h}$ of EF and $5 \mathrm{~d}$ of biological treatment $86 \%$ COD removal was achieved. The treated water can be reused for general purpose in an industrial application.

Dairy industry wastewater has a typical white colour and a high nutrient level as well as organic matter content. It is usually treated by biological methods such as the activated sludge process and anaerobic filters although aerobic biological processes have high energy requirements whilst anaerobic biological methods require additional treatment (Kushwaha et al., 2010). Recently, solar photocatalytic oxidation has been used after anaerobic sludge blanket reactor for the removal of COD from dairy industry wastewater (Banu et al., 2008). The combination of anaerobic process and solar photocatalytic oxidation using $\mathrm{TiO}_{2}$ as a catalyst resulted in 95\% removal of COD from dairy industry wastewater. This integrated system may be a promising alternative for the treatment of dairy industry effluents. In addition, Inamdar \& Singh (2008) have applied photocatalysis in the treatment of dairy industry effluent.

\section{Conclusion}

The characteristics and treatment of food industry wastewaters by different advanced oxidation processes were considered. Typically, the amount and composition of the effluent varies considerably. The high organic matter content is a basic problem in food industry wastewaters but the organic compounds are usually easily biodegradable and the effluents can be treated by conventional anaerobic or aerobic biological methods. However, as a consequence of diverse consumption, the forming effluents may contain compounds which are poisonous to micro-organisms in the biological treatment plant. The pre-treatment of the effluent by chemical oxidation, especially with AOPs, can oxidise biorefractory pollutants to a more easily biodegradable form. Thus, the combination of AOP and biological treatment may be a possible solution for the treatment of variable food industry wastewaters. 


\section{Acknowledgements}

This review has been carried out with the financial support of the Maj and Tor Nessling Foundation and the Finnish Funding Agency for Technology and Innovation (within project 70023/08) from the European Regional Development Fund.

\section{References}

Abdo, M.S.E.; Shaban, H. \& Bader, M.S.H. (1988) Decolorization by ozone of direct dyes in presence of some catalysts. Journal of Environmental Science and Health. Part A, Vol. 23, No. 7, pp. 697-710, ISSN 1077-1204

Ahmadi, M.; Vahabzadeh, F.; Bonakdarpour, B.; Mofarrah, E. \& Mehranian, M. (2005) Application of the central composite design and response surface methodology to the advanced treatment of olive oil processing wastewater using Fenton's peroxidation. Journal of Hazardous Materials, Vol. 123, No. 1-3, pp. 187-195, ISSN 0304-3894

Andreozzi, R.; Caprio, V.; Insola, A. \& Marotta, R. (1999) Advanced oxidation processes (AOP) for water purification and recovery. Catalysis Today, Vol. 53, No, 1, pp. 51-59, ISSN 0920-5861

Andreozzi, R.; Caprio, V.; Marotta, R. \& Radovnikov, A. (2003). Ozonation and $\mathrm{H}_{2} \mathrm{O}_{2} / \mathrm{UV}$ treatment of clorifibric in water: a kinetic investigation. Journal of Hazardous Materials, Vol. 103, No.3, pp. 233-246, ISSN 0304-3894

APHA (1998) Standard Methods for the Examination of Water and Wastewater, 20th ed., American Public Health Association, Washington, D.C, USA, ISSN 55-1979

Babu, B.R.; Meera, K.S.; Venkatesan, P. \& Sunandha, D. (2010) Removal of fatty acids from palm oil effluent by combined electro-Fenton and biological oxidation process. Water, Air, and Soil Pollution, Vol. 211, No. 1-4, pp. 203-210, ISSN 0049-6979

Banu, J.R.; Anandan, S.; Kaliappan, S. \& Yeom, I.-T. (2008) Treatment of dairy wastewater using ananerobic and solar photocatalytics methods. Solar Energy, Vol. 82, No. 9, pp. 812-819, ISSN 0038-092X

Bautista, P.; Mohedano, A.F.; Casas, J.A.; Zazo, J.A. \& Rodriguez, J.J. (2008) Review An overview of the application of Fenton oxidation to industrial wastewater treatment. Journal of Chemical Technology and Biotechnology, Vol. 83, No. 10, pp. 1323-1338, ISSN 0268-2575

Belkacemi, K.; Larachi, F.; Hamoudi, S. \& Sayari, A. (2000) Catalytic wet oxidation of highstrength alcohol-distillery liquors. Applied Catalysis A: General, Vol.199, No. 2, pp. 199-209, ISSN 0926-860X

Belkacemi, K.; Larachi, F.; Hamoudi, S.; Turcotte, G. \& Sayari, A. (1999) Inhibition and deactivation effects in catalytic wet oxidation of high-strength alcohol-distillery liquors. Industrial \& Engineering Chemistry Research, Vol. 38, No. 6, pp. 2268-2274, ISSN 0888-5885

Beltrán, F.J.; Encinar, J.M. \& González, J.F. (1997b) Industrial wastewater advanced oxidation. Part 2. Ozone combined with hydrogen peroxide or UV radiation. Water Research, Vol.31, No.10, pp. 2415-2428, ISSN 0043-1354

Beltrán, F.J.; García-Araya, J. \& Álvarez, P.M. (1999) Wine distillery wastewater degradation. 1. Oxidative treatment using ozone and its effect on the wastewater 
biodegradability. Journal of Agricultural and Food Chemistry, Vol. 47, No. 9, pp. 39113918, ISSN 0021-8561

Beltrán, F.J.; González, M. \& González, J.F. (1997a) Industrial wastewater advanced oxidation. Part 1 . UV radiation in the presence and absence of hydrogen peroxide. Water Research, Vol.31, No.10, pp. 2405-2414, ISSN 0043-1354

Beltrán, F.J.; Rivas, F.J. \& Montero-de-Espinosa, R. (2004) A $\mathrm{TiO}_{2} / \mathrm{Al}_{2} \mathrm{O}_{3}$ catalyst to improve the ozonation of oxalic acid in water. Applied Catalysis B: Environmental, Vol. 47, No. 2, pp. 101-109, ISSN 0926-3373

Beltran-Heredia, J.; Torregrosa, J.; Dominguez, J.R. \& Garcia, J. (2000) Aerobic biological treatment of black table olive washing wastewaters: effect of an ozonation stage. Process Biochemistry, vol. 35, No.10, pp. 1183-1190, ISSN 0032-9592

Benitez, F.J.; Acero, J.L. \& Real, F.J. (2002) Degradation of carbofuran by using ozone, UV radiation and advanced oxidation processes. Journal of Hazardous Materials, Vol. 89 No. 1, pp. 51-65, ISSN 0304-3894

Benitez, F.J.; Acero, J.L.; Gonzalez, T. \& Garcia, J. (2001a) Ozonation and biodegradation processes in batch reactors treating black table olives washing wastewaters. Industrial \& engineering chemistry research, Vol. 40, No. 14, pp. 3144-3151, ISSN 08885885

Benitez, F.J.; Acero, J.L.; Gonzalez, T. \& Garcia, J. (2001b) Organic matter removal from wastewaters of the black olive industry by chemical and biological procedures. Process Biochemistry, Vol. 37, No. 3, pp. 257-265, ISSN 0032-9592

Benitez, F.J.; Beltran-Heredia, J.; Real, F.J. \& Acero, J.L. (1999) Enhancement of the ozonation of wine distillery wastewaters by an aerobic pretreatment. Bioprocess Engineering, Vol. 21, No. 5, pp. 459-464, ISSN 0178-515X

Benitez, F.J.; Real, F.J.; Acero, J.L.; Garcia, J. \& Sanchez, M. (2003) Kinetics of the ozonation and aerobic biodegradation of wine vinasses in discontinuous and continuous processes. Journal of Hazardous Materials, Vol. 101, No. 2, pp. 203-218, ISSN 03043894

Bressan, M.; Liberatore, L.; D álessandro, N.; Tonucci, L.; Belli, C. \& Ranalli, G. (2004) Improved combined chemical and biological treatments of olive oil mill wastewaters. Journal of Agricultural and Food Chemistry, Vol. 52, No. 5, pp. 12281233, ISSN 0021-8561

Çatalkaya, E.Ç. \& Şengül, F. (2006) Application of Box-Wilson experimental design method for the photodegradation of baker's yeast industry with $\mathrm{UV} / \mathrm{H}_{2} \mathrm{O}_{2}$ and $\mathrm{UV} / \mathrm{H}_{2} \mathrm{O}_{2} / \mathrm{Fe}(\mathrm{II})$ process. Journal of Hazardous Materials, Vol. 128, No. 2-3, pp. 201207, ISSN 0304-3894

Caudo, S.; Genovese, C.; Perathoner, S. \& Centi, G. (2008) Copper-pillared clays (Cu-PILC) for agro-food wastewater purification with $\mathrm{H}_{2} \mathrm{O}_{2}$. Microporous and Mesoporous Materials, Vol. 107, No. 1-2, pp. 46-57, ISSN 1387-1811

Chang, C.-C.; Chiu, C.-Y.; Chang, C.-Y.; Chang, C.-F.; Chen, Y.-H.; Ji, D.-R.; Yu, Y.-H. \& Chiang, P.-C. (2009) Combined photolysis and catalytic ozonation of dimethyl phthalate in a high-gravity rotating packed bed. Journal of Hazardous Materials, Vol. 161, No. 1, pp. 287-293, ISSN 0304-3894

Chatzisymeon, E.; Stypas, E.; Bousios, S.; Xekoukoulotakis, N.P. \& Mantzavinos, D. (2008) Photocatalytic treatment of black table olive processing wastewater. Journal of Hazardous Materials, Vol. 154, No. 1-3, pp. 1090-1097, ISSN 0304-3894 
Debellefontaine, H.; Chakchouk, M.; Foussard, J.N.; Tissot, D. \& Striolo, P. (1996) Treatment of organic aqueous wastes: Wet air oxidation and wet peroxide oxidation. Environmental Pollution, Vol. 92, No. 2, pp.155-164, ISSN 0269-7491

Delanoë, F.; Acedo, B.; Karpel Vel Leitner, N. \& Legube, B. (2001) Relationship between the structure of $\mathrm{Ru} / \mathrm{CeO}_{2}$ catalysts and their activity in the catalytic ozonation of succinic acid aqueous solutions. Applied Catalysis B: Environmental, Vol. 29, No. 4, pp. 315-325, ISSN 0926-3373

Dogruel, S.; Olmez-Hanci, T.; Kartal, Z.; Arslan-Alaton, I. \& Orhon, D. (2009) Effect of Fenton's oxidation on the particle size distribution of organic carbon in olive mill wastewater. Water Research, Vol. 43, No. 13, pp. 3974-3983, ISSN 0043-1354

Droste R.L. (1997) Theory and practice of water and wastewater treatment, John Wiley \& Sons, Inc. New York, USA, ISBN 0-471-12444-3

European Commission (August, 2006) Integrated Pollution Prevention and Control: Reference Document on Best Available Techniques in the Food, Drink and Milk Industries, date of access June 15th 2011, Available from: ftp://ftp.jrc.es/pub/eippcb/doc/fdm_bref_0806.pdf

Fallman, H.; Krutzlere, T.; Bauer, R.; Malato, S. \& Blanco, J. (1999) Applicability of the photoFenton method for treating water containing pesticides. Catalysis Today, Vol. 54, No. 2-3, pp. 309-319, ISSN 0920-5861

Finnish Environment Institute (30.9.2009): The industry emissions into waterways 2008, date of access 27th June 2011, Available from

http:/ / www.ymparisto.fi/default.asp?node=24770\&lan=fi

Finnish Food and Drink Industries` Federation (13.12.2010) Yhteenveto Elintarviketeollisuusliiton vuonna 2010 toteuttamasta ympäristövastuun kyselystä, date of access June 27th 2011, Available from:

http://www.etl.fi/www/fi/julkaisut/Julkaisut/Elintarvteoll_ymparistovastuun_r aportti_2010.pdf

Finnish Food and Drink Industries` Federation (2005). Elintarviketeollisuuden ympäristövastuun raportti 2005, Laatuketju, Helsinki, Finland

García-Montaño J.; Torrades, F.; García-Hortal, J.A.; Doménech X. \& Peral, J. (2006) Degradation of Procion RED H-E78 reactive dye by coupling a photo-Fenton system with a sequencing batch reactor. Journal of Hazardous Materials, Vol. 134, No. 1-3, pp. 220-229, ISSN 0304-3894

Gernjak, W.; Maldonado, M.I.; Malato, S.; Cáceres, J.; Krutzler, T.; Glaser, A. \& Bauer, R. (2004) Pilot-plant treatment of olive mill wastewater (OMW) by solar $\mathrm{TiO}_{2}$ photocatalysis and solar photo-Fenton. Solar Energy, Vol. 77, No. 5, pp. 567-572, ISSN 0038-092X

Ginos, A.; Manios, T. \& Mantzavinos, D. (2006) Treatment of olive mill effluents by coagulation-flocculation-hydrogen peroxide oxidation and effect on phytotoxicity. Journal of Hazardous Materials, Vol. 133, No. 1-3, pp. 135-142, ISSN 0304-3894

Gogate, P.R. \& Pandit, A.B. (2004a) A review of imperative technologies for wastewater treatment I: oxidation technologies at ambient conditions. Advances in Environmental Research, Vol. 8, No. 3-4, pp. 501-551, ISSN 1093-0191

Gogate, P.R. \& Pandit, A.B. (2004b) A review of imperative technologies for wastewater treatment II: hybrid methods. Advances in Environmental Research, Vol. 8, No. 3-4, pp. 553-597, ISSN 1093-0191 
Gomes, H.T.; Figueiredo, J.L. \& Faria, J.L. (2007) Catalytic wet air oxidation of olive mill wastewater. Catalysis Today, Vol. 124, No. 3-4, pp. 254-259, ISSN 0920-5861

Gomes, H.T.; Miranda, S.M.; Sampaio, M.J.; Silva, A.M.T. \& Faria, J.L. (2010) Activated carbons treated with sulphuric acid: Catalysts for catalytic wet peroxide oxidation. Catalysis Today, Vol. 151, No. 1-2, pp. 153-158, ISSN 0920-5861

Goto, M.; Nada, T.; Ogata, A.; Kodama, A. \& Hirose, T. (1998) Supercritical water oxidation for the destruction of municipal excess sludge and alcohol distillery wastewater of molasses. Journal of Supercritical Fluids, Vol. 13, No. 1-3, pp. 277-282, ISSN 0896-8446

Gotvajn, A.Z.; Tisler, T. \& Zagorc-Kongan, J. (2009) Comparison of different treatment strategies for industrial landfill leachate. Journal of Hazardous Materials, Vol. 162, No. 2-3, pp. 1446-1456, ISSN 0304-3894

Harada, Y.; Nakashiba, A.; Matuura, H.; Okina, T.; Fujitani, H.; Yamasaki, K.; Doi, Y. \& Yurugi, S. (1987) Process for treating wastewater by wet oxidations. EP: 0224905 (A2)

Harrelkas, F.; Paulo, A.; Alves, M.M.; El Khadir, I.; Zahraa, O.; Pons, M.N. \& van der Zee, F.P. (2008) Photocatalytic and combined anaerobic-photocatalytic treatment of textile dyes. Chemosphere, Vol. 72, No. 11, pp. 1816-1822, ISSN 0045-6535

Heponiemi, A.; Rahikka, L.; Lassi, U. \& Kuokkanen, T. (2009) Catalytic oxidation of industrial wastewaters - a comparison study using different analyzing methods. Chemical Engineering Transactions, Vol. 17, pp. 209-214, ISBN 978-88-95608-01-3

Hiisvirta, L. (1976) Teurastamojen ja lihanjalostuslaitosten jätevesikuormitus ja jätevesien käsittelymahdollisuudet. Vesihallituksen projekti 7406 B, Oy Vesi-hydro AB, Kyriiri Oy, Helsinki, Finland

Hufschmidt, D.; Bahnemann, D.; Testa, J.J.; Emilio, C.A. \& Litter, M.I. (2002) Enhancement of photocatalytic activity of various $\mathrm{TiO}_{2}$ materials by platinization. Journal of Photochemistry and Photobiology, A: Chemistry, Vol. 148, No. 1-3, pp. 223-231, ISSN 1010-6030

Inamdar, J. \& Singh, S.K. (2008) Photocatalytic detoxification method for zero effluent discharge in dairy industry: Effect of operational parameters. International Journal of Chemical and Biological Engineering, Vol. 1, No. 4, pp. 160-164, ISSN 2010-3867

Ishii, T.; Mitsui, K.; Sano, K.; Shishida, K. \& Shiota, Y. (1994) Catalyst for treating wastewater process for producing it, and process for treating wastewater with the catalyst. U.S. Patent $5,374,599$

Johns, M.R. (1995) Developments in wastewater treatment in the meat processing industry: A review. Bioresource Technology, Vol. 54, No. 3, pp. 203-216 ISSN 0960-8524

Kallel, M.; Belaid, C.; Boussahel, R.; Ksibi, M.; Montiela, A. \& Elleuch, B. (2009) Olive mill wastewater degradation by Fenton oxidation with zero-valent iron and hydrogen peroxide. Journal of Hazardous Materials, Vol. 163, No. 2-3, pp. 550-554, ISSN 03043894

Karttunen, E. (2003). RIL 124-1 Vesihuolto I, Finnish Association of Civil Engineers RIL, Vammalan Kirjapaino Oy, Helsinki, Finland, ISBN 951-758-431-8

Katsoni, A.; Frontistis, Z.; Xekoukoulotakis, N.P.; Diamadopoulos, E. \& Mantzavinos, D. (2008) Wet air oxidation of table olive processing wastewater: Determination of key operating parameters by factorial design. Water Research, Vol. 42, No. 14, pp. 35913600, ISSN 0043-1354 
Keav, S.; Martin, A.; Barbier Jr. J. \& Duprez, D. (2010) Deactivation and reactivation of noble metal catalysts tested in the catalytic wet air oxidation of phenol. Catalysis Today, Vol. 151, No. 1-2, pp. 143-147, ISSN 0920-5861

Khoufi, S.; Aloui, F. \& Sayadi, S. (2006) Treatment of olive oil mill wastewater by combined process electro-Fenton reaction and anaerobic digestion. Water Research, Vol. 40, No. 10, pp. 2007-2016, ISSN 0043-1354

Khoufi, S.; Aloui, F. \& Sayadi, S. (2009) Pilot scale hybrid process for olive mill wastewater treatment and reuse. Chemical Engineering and Processing, Vol. 48, No. 2, pp. 643650, ISSN 0255-2701

Kment, S.; Kmentova, H.; Kluson, P.; Krysa, J.; Hubicka, Z.; Cirkva, V.; Gregora, I.; Solcova, O. \& Jastrabik, L. (2010) Notes on the photo-induced characteristics of transition metal-doped and undoped titanium dioxide thin films. Journal of Colloid and Interface Science, Vol. 348, No. 1, pp. 198-205, ISSN 0021-9797

Kolaczkowski, S.T.; Plucinski, P.; Beltran, F.J.; Rivas, F.J. \& McLurgh, D.B. (1999) Wet air oxidation: a review of process technologies and aspects in reactor design. Chemical Engineering Journal, Vol. 73, No. 2, pp. 143-160, ISSN 1385-8947

Kushwaha, J.P.; Srivastava, V.C. \& Mall, I.D. (2010) Organics removal from dairy wastewater by electrochemical treatment and residue disposal. Separation and Purification Technology, Vol. 76, No. 2, pp. 198-205, ISSN 1383-5866

Kyriacou, A.; Lasaridi, K.E.; Kotsou, M.; Balis, C. \& Pilidis, G. (2005) Combined bioremediation and advanced oxidation of green table olive processing wastewater. Process Biochemistry, Vol. 40, pp. 1401-1408, ISSN 0032-9592

Lafi, W.K.; Shannak, B.; Al-Shannag, M.; Al-Anber, Z. \& Al-Hasan, M. (2009) Treatment of olive mill wastewater by combined advanced oxidation and biodegradation. Separation and Purification Technology, Vol. 70, No. 2, pp. 141-146, ISSN 1383-5866

Legrini, O.; Olivieros, E. \& Braun, A.M. (1993) Photochemical processes for water treatment. Chemical Reviews, Vol. 93, No. 2, pp. 671-698, ISSN 0009-2665

Lehto, M.; Salo T.; Sorvala S.; Kemppainen R.; Vanhala P.; Sipilä I.; Puumala M. (2007) Peruna- ja juureskuorimon jätteet ja jätevedet. MTT Tampere: Tampereen Yliopistopaino, Juvenes Print, Finland, ISSN 1458-5073

Levec, J. \& Pintar, A. (2007) Catalytic wet-air oxidation processes: A review. Catalysis Today, Vol. 124, No. 3-4, pp. 172-184, ISSN 0920-5861

Lixiong, L.; Chen, P. \& Gloyna, E.F. (1991) Generalized kinetic model for the wet oxidation of organic compounds. AlChE Journal, Vol. 37, No. 11, pp. 1687-1697, ISSN 00011541

Lopez, A.; Pagano, M.; Volpe, A. \& Di Pinto, A.C. (2004) Fenton`s pre-treatment of mature landfill leachate. Chemosphere, Vol. 54, No.7, pp. 1005-1010, ISSN 0045-6535

Lucas, M.S. \& Peres, J.A. (2009b) Removal of COD from olive mill wastewater by Fenton's reagent: Kinetic study. Journal of Hazardous Materials, Vol. 168, No. 2-3, pp. 12531259, ISSN 0304-3894

Lucas, M.S.; Peres, J.A. \& Puma, G.L. (2010) Treatment of winery wastewater by ozonebased advanced oxidation processes $\left(\mathrm{O}_{3}, \mathrm{O}_{3} / \mathrm{UV}\right.$ and $\left.\mathrm{O}_{3} / \mathrm{UV} / \mathrm{H}_{2} \mathrm{O}_{2}\right)$ in a pilot-scale bubble column reactor and process economics. Separation and Purification Technology, Vol. 72, No. 3, pp. 235-241, ISSN 1383-5866 
Lucas, M.S.; Peres, J.A.; Lan, B.Y. \& Puma, G.L. (2009a) Ozonation kinetics of winery wastewater in a pilot-scale bubble column reactor. Water Research, Vol. 43, No. 6, pp. 1523-1532, ISSN 0043-1354

Luck, F. (1999) Wet air oxidation: past, present and future. Catalysis Today, Vol. 53, No. 1, pp. 81-91, ISSN 0920-5861

Ma, J. \& Graham, N.J.D. (1997) Preliminary investigation of manganese-catalyzed ozonation for the destruction of atrazine. Ozone; Science and Engineering, Vol. 19, No. 3, pp. 227-240, ISSN 0191-9512

Mantzavinos, D. \& Kalogerakis, N. (2005) Treatment of olive mill effluents Part I. Organic matter degradation by chemical and biological processes-an overview. Environment International, Vol. 31, No. 2, pp. 289-295, ISSN 0160-4120

Mantzavinos, D.; Hellenbrand, R.; Livingston, A.G. \& Metcalfe, I.S. (1996a) Catalytic wet oxidation of p-coumaric acid: Partial oxidation intermediates, reaction pathways and catalyst leaching. Applied Catalysis B: Environmental, Vol. 7, No. 3-4, pp. 379-396, ISSN 0926-3373

Mantzavinos, D.; Hellenbrand, R.; Livingston, A.G. \& Metcalfe, I.S. (1996b) Catalytic wet air oxidation of polyethylene glycol. Applied Catalysis B: Environmental, Vol. 11, No. 1, pp. 99-119, ISSN 0926-3373

Masten, S.J. \& Davies, H.R. (1994) The use of ozonation to degrade organic contaminants in wastewater. Environmental Science \& Technology, Vol. 28, No.4, pp. 180-185A, ISSN 0013-936X

Menendez-Flores, V.M.; Bahnemann, D.W. \& Ohno, T. (2011) Visible light photocatalytic activities of S-doped $\mathrm{TiO}_{2}-\mathrm{Fe}^{3+}$ in aqueous and gas phase. Applied Catalysis B: Environmental, Vol. 103, No. 1-2, pp. 99-108, ISSN 0926-3373

Metcalf \& Eddy (2003) Wastewater Engineering: treatment and reuse, 4. ed, McGraw-Hill, Boston, USA, ISBN 0-07-041878-0

Minh, D.P.; Gallezot, P.; Azabou, S.; Sayadi, S. \& Besson, B. (2008) Catalytic wet air oxidation of olive oil mill effluents 4 . Treatment and detoxification of real effluents. Applied Catalysis B: Environmental, Vol. 84, No. 3-4, pp. 749-757, ISSN 0926-3373

Mishra, V.S.; Mahajani, V.V. \& Joshi, J.B. (1995) Wet Air Oxidation. Industrial \& Engineering Chemistry Research, Vol.34, No.1, pp. 2-48, ISSN 0888-5885

Munter R. (2001) Advanced oxidation processes - Current status and prospects. Proceedings of the Estonian Academy of Sciences, Chemistry, Vol. 50, No. 2, pp. 59-80, ISSN 14060124)

OECD guidelines for the testing of chemicals (1992) Test no. 301: Ready biodegradability: $301 \mathrm{~F}$. Manometric respirometry. OECD, 1992

Oller, I.; Malato, S. \& Sánchez-Pérez, J.A. (2010) Combination of advanced oxidation processes and biological treatments for wastewater decontamination - review. Science of the Total Environment, doi: 10.1016/j.scitotenv.2010.08.061 (article in press, No of pages 26), ISSN 0048-9697

Pala, A. \& Erden, G. (2005) Decolorization of baker's yeast industry effluent by Fenton oxidation. Journal of Hazardous Materials, Vol. 127, No. 1-3, pp. 141-148, ISSN 03043894

Pérez, M.; Torrades, F.; Peral, J.; Lizama, C.; Bravo, C.; Casas, S.; Freer, J. \& Mansilla, H.D. (2001) Multivariate approach to photocatalytic degration of cellulose bleaching affluent. Applied Catalysis B: Environmental, Vol. 33, No. 2, pp. 89-96, ISSN 0926-3373 
Rivas, F.J.; Beltrán, F.J. \& Gimeno, O. (2000) Joint treatment of wastewater from table olive processing and urban wastewater. Integrated ozonation - aerobic oxidation. Chemical Engineering \& Technology, Vol. 23, No. 2, pp. 177-181, ISSN 0930-7516

Rivas, F.J.; Beltrán, F.J.; Gimeno, O. \& Alvarez, P. (2001) Chemical-biological treatment of table olive manufacturing wastewater. Journal of Environmental Engineering, Vol. 127, No. 7, pp. 611-619, ISSN 0733-9372

Rizzo, L.; Lofrano, G.; Grassi, M. \& Belgiorno, V. (2008) Pre-treatment of olive mill wastewater by chitosan coagulation and advanced oxidation processes. Separation and Purification Technology, Vol. 63, No. 3, pp. 648-653, ISSN 1383-5866

Rokhina, E.V.; Repo, E. \& Virkutyte, J. (2010) Comparative kinetic analysis of silent and ultrasound-assisted catalytic wet peroxide oxidation of phenol. Ultrasonics Sonochemistry, Vol. 17, No. 3, pp. 541-546, ISSN 1350-4177

Sangave, P.C.; Gogate, P.R. \& Pandit, A.B. (2007) Combination of ozonation with conventional aerobic oxidation for distillery wastewater treatment. Chemosphere, Vol. 68, No. 1, pp. 32-41, ISSN 0045-6535

Sena, R.F.; Tambosi, J.L.; Genena, A.K.; Moreira, R.F.P.M.; Schröder, H.F.R. \& José, H.J. (2009) Treatment of meat industry wastewater using dissolved air flotation and advanced oxidation processes monitored by GC-MS and LC-MS. Chemical Engineering Journal, Vol. 152, No. 1, pp. 151-157, ISSN 1385-8947

SES (1994) The UV/Oxidation Handbook, Solarchem Environmental Systems, Markham, Ontario, Canada

SFS 3020 (1979) Determination of chemical oxygen demand $\left(C O D_{C r}\right)$ in water. Oxidation with dichromate, Finnish Standards Association SFS, Helsinki, Finland

SFS-EN 1484 (1997) Water analysis. Guidelines for the determination of total organic carbon (TOC) and dissolved organic carbon (DOC), Finnish Standards Association SFS, Helsinki, Finland

SFS-EN 1899-1 (1998) Water quality. Determination of biochemical oxygen demand after $n$ days (BODn). Part I: Dilution and seeding method with allylthiourea addition, Finnish Standards Association SFS, Helsinki, Finland

Sreethawong, T. \& Chavadej, S. (2008) Color removal of distillery wastewater by ozonation in the absence and presence of immobilized iron oxide catalyst. Journal of Hazardous Materials, Vol. 155, No. 3, pp. 486-493, ISSN 0304-3894

Sroka, E.; Kamfliski, W. \& Bohdziewicz, J. (2004) Biological treatment of meat industry wastewater. Desalination, Vol. 162, No.10, pp. 85-91, ISSN 0011-9164

Staehelin, J. \& Hoigne, J. (1982) Decomposition of ozone in water: rate of initiation of hydrogen ions and hydrogen peroxide. Environmental Science and Technology, Vol. 16, No. 10, pp. 676-681, ISSN 0013-936X

Szpyrkowicz, L.; Juzzolino, C. \& Kaul, S.N. (2001) A comparative study on oxidation of disperse dyes by electrochemical process, ozone, hypochlorite and Fenton reagent. Water Research, Vol. 35, No. 9, pp. 2129-2136, ISSN 0043-1354

Verenich, S. (2003) Wet oxidation of concentrated wastewaters: process combination and reaction kinetic modeling, PhD thesis, Lappeenranta University of Technology, Lappeenranta, Finland, ISBN 951-764-739-5

Wang, P.H.; Yap, P.S. \& Lim, T.T. (2011) C-N-S tridoped $\mathrm{TiO}_{2}$ for photocatalytic degradation of tetracycline under visible light irradiation. Applied Catalysis A - General, Vol. 399, No. 1-2, pp. 252-261, ISSN 0926-860X 
Yavuz, Y. (2007) EC and EF processes for the treatment of alcohol distillery wastewater. Separation and Purification technology, Vol. 53, No. 1, pp. 135-140, ISSN 1383-5866

Zayas, P.T.; Geissler, G. \& Hernandez, F. (2007) Chemical oxygen demand reduction in coffee wastewater through chemical flocculation and advanced oxidation processes. Journal of Environmental Sciences, Vol. 19, No. 3, pp. 300-305, ISSN 10010742

Zinatizadeh, A.A.L.; Mohamed, A.R.; Najafpour, G.D.; Hasnanin Isa, M. \& Nasrollahzadeh, H. (2006) Kinetic evaluation of palm oil mill effluent digestion in a high rate upflow anaerobic sludge fixed film bioreactor. Process Biochemistry, Vol. 41, No. 5, pp. 1038-1046, ISSN 1359-5113 


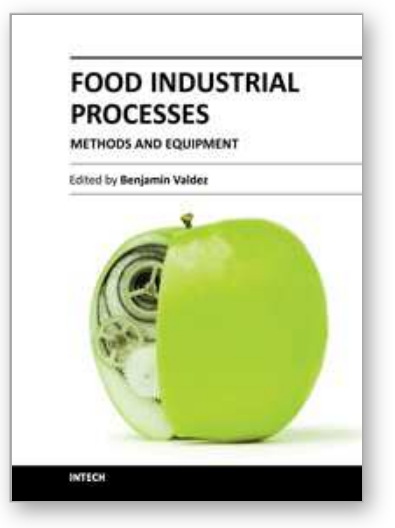

\author{
Food Industrial Processes - Methods and Equipment \\ Edited by Dr. Benjamin Valdez
}

ISBN 978-953-307-905-9

Hard cover, 418 pages

Publisher InTech

Published online 22, February, 2012

Published in print edition February, 2012

The global food industry has the largest number of demanding and knowledgeable consumers: the world population of seven billion inhabitants, since every person eats! This population requires food products that fulfill the high quality standards established by the food industry organizations. Food shortages threaten human health and are aggravated by the disastrous, extreme climatic events such as floods, droughts, fires, storms connected to climate change, global warming and greenhouse gas emissions that modify the environment and, consequently, the production of foods in the agriculture and husbandry sectors. This collection of articles is a timely contribution to issues relating to the food industry. They were selected for use as a primer, an investigation guide and documentation based on modern, scientific and technical references. This volume is therefore appropriate for use by university researchers and practicing food developers and producers. The control of food processing and production is not only discussed in scientific terms; engineering, economic and financial aspects are also considered for the advantage of food industry managers.

\title{
How to reference
}

In order to correctly reference this scholarly work, feel free to copy and paste the following:

Anne Heponiemi and Ulla Lassi (2012). Advanced Oxidation Processes in Food Industry Wastewater Treatment - A Review, Food Industrial Processes - Methods and Equipment, Dr. Benjamin Valdez (Ed.), ISBN: 978-953-307-905-9, InTech, Available from: http://www.intechopen.com/books/food-industrial-processesmethods-and-equipment/advanced-oxidation-processes-in-food-industry-wastewater-treatment-a-review

\section{INTECH}

open science | open minds

\section{InTech Europe}

University Campus STeP Ri

Slavka Krautzeka 83/A

51000 Rijeka, Croatia

Phone: +385 (51) 770447

Fax: +385 (51) 686166

www.intechopen.com

\section{InTech China}

Unit 405, Office Block, Hotel Equatorial Shanghai

No.65, Yan An Road (West), Shanghai, 200040, China

中国上海市延安西路65号上海国际贵都大饭店办公楼405单元

Phone: +86-21-62489820

Fax: $+86-21-62489821$ 
(C) 2012 The Author(s). Licensee IntechOpen. This is an open access article distributed under the terms of the Creative Commons Attribution 3.0 License, which permits unrestricted use, distribution, and reproduction in any medium, provided the original work is properly cited. 